\title{
Kemampuan Berpikir Logis Matematis Materi Pecahan pada Siswa Berkemampuan Awal Tinggi
}

\author{
Lilis Wulandari' ${ }^{1}$, Ulum Fatmahanik ${ }^{2)}$ \\ ${ }^{1,2)}$ Institut Agama Islam Negeri Ponorogo \\ Email : wulandarililis26@gmail.com,ulum.fatma@gmail.com
}

\begin{abstract}
This research aims to describe the mathematical logical thinking ability of fourth grade students of MI Darussalam Lembeyan Kulon, Lembeyan Subdistrict, Magetan, having high initial ability in solving fraction problems. This type of research is qualitative descriptive. The research subjects were all grade IV students number of 24 students and then taken by 1 student with high initial ability. Data is collected by providing tests in the form of questions with answers that refer to mathematical logical thinking indicators and conducting interviews. The results showed that students with high initial ability were able to fulfill all indicators of mathematical logical thinking, namely: (1) the stage of understanding the problem (2) the stage of planning the completion of the problem (3) determining the steps that would be used in solving the problem (4) the stage of solving the problem (5) the stage provides a logical conclusion on the final answer.
\end{abstract}

Keywords : Mathematical Logical Thinking, High Initial Ability, Fraction.

\begin{abstract}
ABSTRAK
Penelitian ini bertujuan untuk mendeskripsikan kemampuan berpikir logis matematis siswa kelas IV MI Darussalam Lembeyan Kulon Kecamatan Lembeyan Kabupaten Magetan berkemampuan awal tinggi dalam menyelesaikan soal pecahan. Jenis penelitian ini adalah penelitian deskriptif kualitatif. Subjek penelitian seluruh siswa kelas IV yang berjumlah 24 siswa kemudian di ambil 1 siswa berkemampuan awal tinggi. Pengambilan data dilakukan dengan cara memberikan tes dalam bentuk soal dengan jawaban yang mengacu pada indikator berpikir logis matematis dan melakukan wawancara. Hasil penelitian menunjukkan bahwa siswa berkemampuan awal tinggi mampu memenuhi semua indikator berpikir logis matematis, yaitu: (1) tahap memahami soal (2) tahap merencanakan penyelesaian soal (3) menentukan langkah-langkah yang akan digunakan dalam menyelesaikan soal (4) tahap menyelesaikan soal (5) tahap memberikan kesimpulan yang logis pada hasil akhir jawaban.
\end{abstract}

Kata Kunci : Berpikir Logis Matematis, Kemampuan Awal Tinggi, Pecahan. 


\section{PENDAHULUAN}

Berpikir merupakan proses kognitif yang tidak dapat dilihat secara fisik, hasil dari berpikir dapat berupa ide, pengetahuan, argumen, dan keputusan. Berpikir matematik dapat diartikan sebagai aktivitas mental dalam melaksanakan proses matematika atau tugas matematika (Abdullah, 2016). Proses berpikir merupakan aktivitas yang terjadi di otak manusia sehingga sulit di amati oleh alat indra, proses berpikir tersebut dapat diketahui dari perilaku yang tampak dalam memecahkan masalah. Pemecahan suatu masalah dibutuhkan pemikiran logis, hal ini berhubungan dengan kecerdasan yang dimiliki seseorang. Kemampuan berfikir matematis merupakan faktor yang sangat berpengaruh terhadap perkembangan pengetahuan yang meliputi penerapan pengetahuan dan keterampilan serta mampu memunculkan kemampuan untuk belajar mandiri. Salah satu kemampuan berfikir matematis yang harus dimiliki seseorang adalah kemampuan berfikir logis matematis.

Salah satu materi matematika yang harus dikuasai oleh siswa adalah materi pecahan. Pembelajaran matematika mengenai pecahan di sekolah dasar kelas empat bukanlah yang pertama kali bagi siswa. Materi ini pernah diterima siswa pada saat masih duduk di kelas satu, kelas dua dan kelas tiga. Sehingga siswa tentu sudah tidak asing dengan materi ini, dalam sruktur kognitif siswa sudah terbentuk pengertian pecahan dan siswa sudah memiliki kemampuan awal dalam menyelesaikan soal matematika materi pecahan. Namun masalah pecahan masih menjadi materi yang sulit bagi siswa.

Secara umum kemampuan siswa dalam menyelesaikan soal pecahan masih tergolong rendah. Hal ini dapat dibuktikan dengan hasil TIMSS 2015 rata-rata skor persentase jawaban benar siswa Indonesia untuk seluruh soal pecahan adalah sebesar $24,45 \%$. Persentase ini jauh dibawah rata-rata internasional, yaitu 46,98\%. Hasil siswa Indonesia pada TIMSS Numeracy juga lebih rendah dari persentase jawaban benar siswa negara dengan skor TIMSS di bawah Indonesia, yaitu Yordania sebesar 46,7\% dan Afrika Selatan sebesar 48,72\% (Fatmahanik, 2019).

Hasil tersebut menunjukkan bahwa kemampuan siswa Indonesia dalam materi pecahan masih rendah. Kemampuan berpikir matematis yang dimiliki oleh siswa belum berkembang secara optimal. Hal ini juga ditunjukkan pada siswa kelas IV 
di MI Darussalam Lembeyan Kulon, dari hasil wawancara dengan guru Matematika yang ada di MI Darussalam Lembeyan Kulon, bahwasanya siswa kelas IV dalam menyelesaikan persoalan pecahan masih perlu di perbaiki, dari 24 siswa yang benarbenar paham mengenai materi pecahan hanya 50\% siswa dan yang lainnya paham akan tetapi sedikit lambat. Proses berpikir siswa menunjukkan keseriusan dalam belajar. Dalam proses pembelajaran seharusnya guru selalu memperhatikan kemampuan berpikir matematika siswa.

Kecerdasan logis matematis adalah kemampuan dalam memahami hubunganhubungan humanikal. Mereka yang memiliki kecerdasan ini adalah mereka yang bekerja dengan simbol-simbol abstrak dan bisa melihat koneksi antara potonganpotongan informasi yang mungkin terlewatkan oleh orang lain (Efendi, 2005). Kecerdasan logis matematis memuat kemampuan seseorang dalam berpikir secara induktif dan deduktif, berpikir menurut aturan logika, memahami dan menganalisis pola angka-angka, serta memecahkan masalah dengan menggunakan kemampuan berpikir (Uno, 2009). Berpikir logis itu penting karena anak-anak memperoleh disiplin mental dan belajar menentukan apakah alur pikir itu benar dan tidak benar.

Indikator berpikir logis matematis menurut Lestari (Lestari, n.d.) adalah:

1) Membuat makna tentang jawaban argumen yang masuk akal.

2) Membuat hubungan logis di antara konsep dan fakta yang berbeda.

3) Menduga dan menguji berdasarkan akal.

4) Menyelesaikan masalah matematis secara rasional.

5) Menarik kesimpulan yang logis.

Kecerdasan logis matematis merupakan kemampuan seseorang untuk menggunakan penalaran, logika dan angka-angka. Siswa yang menonjol dalam intelegensi ini cenderung untuk berpikir secara konseptual dalam kerangka logika dan angka yang digunakan dalam membuat hubungan antara berbagai informasi yang di dapatnya.(Purwaningrum \& Sumardi, 2016a) Definisi dari kecerdasan logika dan angka adalah kecerdasan untuk memahami kondisi atau situasi dengan menggunakan perhitungan matematis, serta melalui penalaran logika. Rose Mini (Mini, 2010) menyatakan jenis kecerdasan ini melibatkan keterampilan seseorang untuk mengolah angka, serta kemahiran dalam menggunakan logika dan akal sehat. Lebih jauh lagi, 
kecerdasan logika matematika melibatkan kemampuan seseorang untuk berpikir secara abstrak, menyusun strategi penyelesaian masalah, serta menjawab berbagai pertanyaan yang kompleks. Jika seseorang sudah terbiasa mengasah logika berpikirnya dalam memecahkan masalah matematika maka mereka akan terbiasa juga untuk berpikir secara nalar, kritis, runtut dan konsisten.

Berdasarkan uraian diatas maka dapat disimpulkan bahwa kecerdasan logis matematis atau kecerdasan logika matematika berguna untuk memecahkan permasalahan yang berkaitan dengan angka-angka dan dalam masalah dilingkungan sekitarnya dalam kehidupan sehari-hari. Anak yang memiliki kecerdasan logis matematis yang tinggi cenderung menyenangi kegiatan menganalisis dan mempelajari sebab-akibat terjadi sesuatu. Apabila kurang memahami, dia akan cenderung akan berusaha untuk bertanya dan mencari jawaban atas hal yang kurang dipahaminya. Kecerdasan logis matematis bukanlah satu-satunya kecerdasan yang dimiliki manusia. Manusia terlahir kedunia ini, dianugerahi segala potensi dan kecerdasan yang dapat dikembangkan dalam proses kehidupannya. Untuk menggali proses berpikir logis siswa bisa dengan memberikan soal-soal tes materi matematika dan dalam prosesnya tidak lepas dari kemampuan awal siswa.

Kemampuan awal siswa adalah kemampuan yang telah dipunyai siswa sebelum ia mengikuti pembelajaran. Kemampuan awal dalam pembelajaran matematika penting untuk diketahui guru sebelum memulai pembelajaran. Hal ini berguna untuk mengetahui apakah siswa mempunyai pengetahuan prasyarat (prerequisite) untuk mengikuti pembelajaran dan sejauh mana siswa telah mengetahui materi yang akan disajikan, sehingga guru dapat merancang pembelajaran lebih baik (Purwaningrum \& Sumardi, 2016b). Peserta didik dapat menghubungan berbagai pengetahuan yang telah dimilikinya untuk pengetahuan baru.

Kemampuan awal disini adalah pengetahuan awal siswa mengenai materi yang menjadi prasyarat untuk mempelajari materi selanjutnya. Dalam memahami pelajaran siswa bergantung pada kemampuan awal yang menyediakan ingatan untuk siswa dalam menemukan informasi yang mereka butuhkan dan kapan mereka butuhkan. Kemampuan awal matematis siswa dapat mempermudah dalam pengerjaan soal matematika. 
Menurut Muchlishin (Akramunnisa \& Sulestry, 2016) kemampuan awal matematika adalah suatu kesanggupan yang dimiliki oleh peserta didik baik alami maupun yang dipelajari untuk melaksanakan suatu tindakan tertentu secara historis dimana mereka memberikan respon yang positif atau negative terhadap objek tersebut dengan menggunakan penalaran dan cara-cara berpikir logis, analistis, sistematis, kritis, kreatif, dan inovatif serta menekankan pada penguasaan konsep disamping kemampuan pemecahan masalah. Kemampuan awal ini akan erat kaitannya dengan siswa menyelesaikan soal matematika.

Kemampuan awal dalam pembelajaran penting untuk diketahui oleh guru sebelum memulai pembelajaran, karena dengan demikian dapat diketahui sejauh mana siswa telah mengetahui materi apa yang akan disajikan oleh guru dan apakah siswa telah mempunyai pengetahuan yang merupakan prasyarat untuk mengikuti pembelajaran (Lwin et al., 2008). Dengan mengetahui kedua hal tersebut, guru akan dapat merancang pembelajaran dengan lebih baik, sebab apabila siswa diberi materi yang telah diketahui maka mereka akan merasa cepat bosan. Karena kemampuan awal tersebut sangat penting untuk diketahui guru sebelum memulai pembelajaran. Maka dengan hal ini akan mudah untuk menggali kemampuan berpikir logis siswa dalam menyelesaikan persoalan pecahan yang masih rendah. Karena ketika guru mengetahui cara berpikir siswa memudahkan mereka dalam memilih cara belajar yang tepat dengan tingkat kecerdasan logis matematis mereka. Pemahaman guru terhadap proses berpikir siswa sangat membantu dalam pembelajaran matematika. Sehingga hasil akhir dari kemampuan berpikir logis siswa dalam menyelesaikan persoalan pecahan dapat meningkatkan keberhasilan dan mencapai tujuan belajar matematika.

Penelitian ini bertujuan untuk mendeskripsikan kemampuan berpikir logis matematis siswa kelas IV MI Darussalam Lembeyan Kulon Kecamatan Lembeyan Kabupaten Magetan berkemampuan awal tinggi dalam menyelesaikan soal pecahan

\section{METODE PENELITIAN}

Penelitian ini dilaksanakan di MI Darussalam Lembeyan Kulon menggunakan subjek kelas IV yang berjumlah 24 siswa kemudian diambil 1 siswa berkemampuan awal tinggi. Selanjutnya dalam menentukan subjek penelitian, peneliti 
memilih siswa dari kemampuan awal tinggi yang dapat berkomunikasi dengan baik dan atas pertimbangan guru matematika yang mengajar dikelas tersebut. Penelitian ini termasuk kedalam jenis penelitian kualitatif studi kasus.

Kemampuan awal berpikir logis matematis siswa dalam penelitian ini diperoleh dari nilai tes kemampuan awal materi pecahan kelas IV MI Darussalam Lembeyan Kulon, yang dibedakan dalam tiga kategori yaitu tinggi, sedang, dan rendah berdasarkan rumus acuan norma menurut Suharsimi Arikunto (Suharsimi, 2009) dapat dilihat pada tabel berikut

Tabel 1. Rumus Acuan Norma

\begin{tabular}{cc}
\hline Skor $(\mathbf{S})$ & Kelompok \\
\hline $\mathrm{S} \geq(\bar{x}+\mathrm{DS})$ & Tinggi \\
\hline$(\bar{x}-\mathrm{DS})<\mathrm{s}<(\bar{x}+\mathrm{DS})$ & Sedang \\
\hline $\mathrm{S} \leq(\bar{x}-\mathrm{DS})$ & Rendah \\
\hline
\end{tabular}

Teknik pengumpulan data pada penelitian ini meliputi: tes tulis, wawancara, dan dokumentasi. Dengan menggunakan instrumen penelitian berupa kisi-kisi soal tes kemampuan berpikir logis matematis mengenai materi pecahan yang mengacu pada indikator kemampuan berpikir logis matematis, dan pedoman wawancara. Teknik analisis data yang digunakan dalam penelitian ini adalah: (1) reduksi data, (2) penyajian data, (3) penarikan kesimpulan.

Tabel 2. Indikator Penyusun Instrumen Kemampuan Berpikir Logis Siswa

\begin{tabular}{|c|c|}
\hline Indikator Berpikir Logis Matematis & Uraian \\
\hline $\begin{array}{l}\text { Membuat makna tentang jawaban } \\
\text { argumen yang masuk akal. }\end{array}$ & $\begin{array}{l}\text { 1. Siswa mampu memahami maksud dari soal yang } \\
\text { diberikan. } \\
\text { 2. Siswa menyebutkan seluruh informasi dari apa yang } \\
\text { diketahui dari soal (mampu merumuskan pokok-pokok } \\
\text { permasalahan). }\end{array}$ \\
\hline $\begin{array}{l}\text { Membuat hubungan logis diantara konsep } \\
\text { dan fakta yang berbeda. }\end{array}$ & $\begin{array}{l}\text { 1. Siswa dapat merencanakan penyelesaian soal yang } \\
\text { diberikan. } \\
\text { 2. Siswa dapat mengungkapkan secara umum semua } \\
\text { langkah yang akan digunakan dalam menyelesaikan soal } \\
\text { yang diberikan. }\end{array}$ \\
\hline
\end{tabular}




\begin{tabular}{lrl}
\hline \multicolumn{1}{c}{ Indikator Berpikir Logis Matematis } & \multicolumn{1}{c}{ Uraian } \\
\hline Menduga dan menguji berdasarkan akal. & 1. $\begin{array}{l}\text { Siswa dapat menentukan strategi atau langkah-langkah } \\
\text { yang akan digunakan dalam menyelesaikan soal yang } \\
\text { diberikan. }\end{array}$ \\
\hline Menyelesaikan masalah matematis & 1. & $\begin{array}{l}\text { Siswa dapat menyelesaikan soal secara tepat pada setiap } \\
\text { langkah yang digunakan } \\
\text { secara rasional. }\end{array}$ \\
& 2. & $\begin{array}{l}\text { Siswa menetapkan kebenaran dari setiap langkah yang } \\
\text { digunakan dalam menyelesaikan soal. }\end{array}$ \\
& 1. $\begin{array}{l}\text { Siswa memberikan kesimpulan dengan tepat pada tiap } \\
\text { langkah penyelesaian. }\end{array}$ \\
\hline Menarik kesimpulan yang logis. & 2. $\begin{array}{l}\text { Siswa dapat menyimpulkan dengan tepat pada hasil } \\
\text { akhir jawaban. }\end{array}$ \\
\hline
\end{tabular}

\section{HASIL DAN PEMBAHASAN}

\section{Hasil Penelitian}

Berdasarkan hasil tes kemampuan berpikir logis matematis pada materi pecahan yang diberikan kepada siswa kelas IV di MI Darussalam Lembeyan Kulon, peneliti akan menjabarkan aktivitas kemampuan berpikir logis matematis siswa berkemampuan awal tinggi. Penjabaran kemampuan berpikir logis matematis siswa akan diuraikan mulai dari membuat makna tentang jawaban argumen yang masuk akal (memahami soal), membuat hubungan logis diantara konsep dan fakta yang berbeda (perencanaan), menduga dan menguji berdasarkan akal dan menyelesaikan masalah secara rasional (menyelesaikan soal), dan menarik kesimpulan yang logis. Berikut uraian aktivitas kemampuan berpikir logis matematis siswa berkemampuan awal tinggi:

Pada soal nomor 1 tahap membuat makna tentang jawaban argumen yang masuk akal (memahami soal), siswa mampu menuliskan informasi yang terdapat dalam permasalahan (soal) yang diberikan. Hal ini menunjukkan bahwa siswa telah mampu membuat makna tentang jawaban argumen yang masuk akal pada tahap memahami soal. Hal ini dapat dilihat pada lembar jawaban siswa.

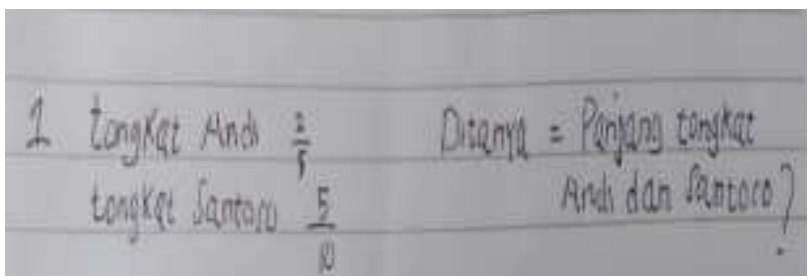


Gambar 1. Jawaban Siswa Soal Nomor 1 Tahap Memahami Soal

Pada tahap membuat hubungan yang logis diantara konsep dan fakta yang berbeda, menduga dan menguji berdasarkan akal (perencanaan), siswa mampu menemukan hubungan antara apa yang diketahui dan ditanyakan dari soal yang diberikan. Sehingga siswa mampu pada tahap menduga dan menguji berdasarkan akal dan menemukan strategi yang dapat digunakan untuk menemukan jawaban. Pada tahap menyelesaikan masalah matematis secara rasional siswa mampu menyelesaikan soal sesuai dengan strategi yang digunakan. Dalam lembar jawaban soal siswa menyelesaikan soal dengan menyamakan penyebut terlebih dahulu. Hal ini dapat dilihat pada lembar jawaban siswa.

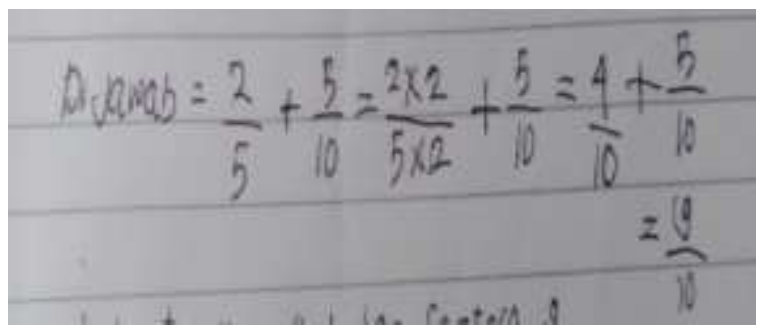

Gambar 2. Jawaban Siswa Soal Nomor 1 Tahap Menyelesaikan Soal

Siswa juga mampu menarik kesimpulan yang logis dengan jawaban yang telah diberikan. Siswa menuliskan kesimpulan pada lembar jawaban dengan singkat dan ketika diwawancarai pun siswa juga mampu memberi kesimpulan atas jawaban yang telah didapat. Hal ini dapat dilihat pada lembar jawaban siswa.

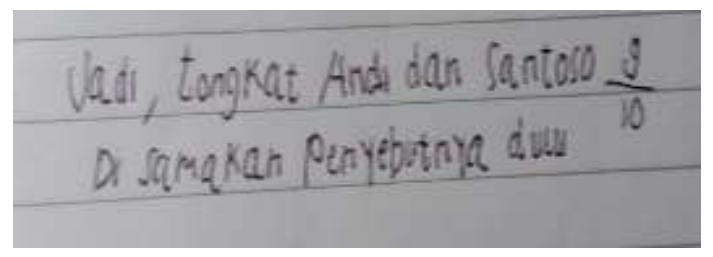

Gambar 3. Jawaban Siswa Soal Nomor 1 Tahap Memberikan Kesimpulan

Siswa berkemampuan awal tinggi dalam mengerjakan soal nomor 2 tahap membuat makna tentang jawaban argumen yang masuk akal (memahami soal), siswa mampu menuliskan informasi yang terdapat dalam soal, baik yang diketahui maupun yang ditanya. Hal ini dapat dilihat pada lembar jawaban siswa. Sehingga siswa telah 
mampu membuat makna tentang jawaban argumen yang masuk akal (memahami soal yang telah diberikan).

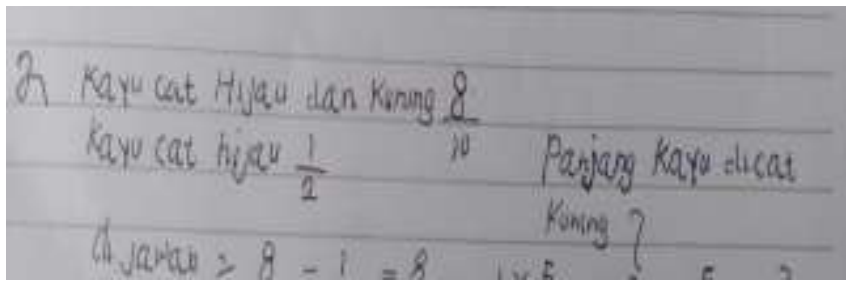

Gambar 4. Jawaban Siswa Soal Nomor 2 Tahap Memahami Soal

Pada tahap membuat hubungan yang logis diantara konsep dan fakta yang berbeda, menduga dan menguji berdasarkan akal (perencanaan), siswa mampu menemukan hubungan antara apa yang diketahui dan ditanyakan dalam soal yang diberikan. Hal ini dapat dilihat ketika ditanya, siswa menjelaskan strategi yang akan digunakan untuk menemukan jawaban. Sehingga siswa mampu menduga dan menguji berdasarkan akal dan mampu menemukan strategi yang dapat digunakan untuk menjawab soal.

Pada tahap menyelesesaikan masalah matematis secara rasional siswa mampu menyelesaikan soal dengan strategi yang digunakannya dan sesuai dengan tahap perencanaan yang dipilihnya, ini menunjukkan bahwa siswa telah mampu pada tahap menyelesaikan masalah. Hal ini dapat dilihat pada lembar jawaban siswa.

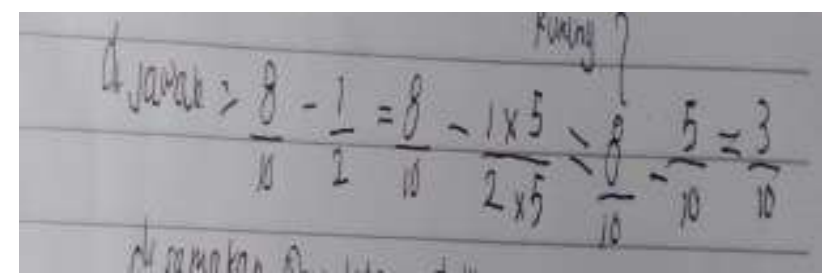

Gambar 5. Jawaban Siswa Soal Nomor 2 Tahap Menyelesaikan Soal

Siswa juga mampu menarik kesimpulan yang logis dengan jawaban yang telah diberikan pada soal nomor 2. Hal ini dapat dilihat pada lembar jawaban siswa.

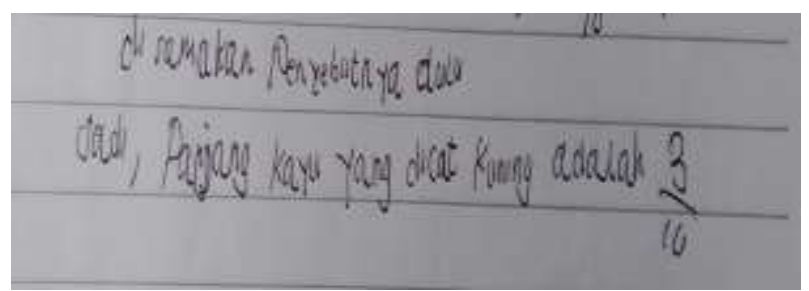

Gambar 6. Jawaban Siswa Soal Nomor 2 Tahap Memberi Kesimpulan 
Pada soal nomor 3 tahap membuat makna tentang jawaban argumen yang masuk akal (memahami soal), dalam lembar jawaban siswa mampu menuliskan informasi yang terdapat dalam soal baik yang diketahui maupun yang ditanya. Sehingga siswa telah mampu memahami soal yang telah diberikan.

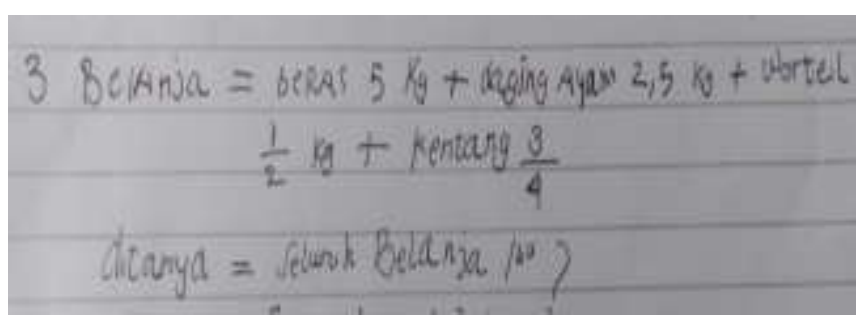

Gambar 7. Jawaban Siswa Soal Nomor 3 Tahap Memahami Soal

Pada tahap membuat hubungan logis diantara konsep dan fakta yang berbeda, menduga dan menguji berdasarkan akal (perencanaan), siswa mampu menemukan hubungan antara apa yang diketahui dan ditanyakan dalam permasalahan. Hal ini dapat dilihat ketika ditanya, siswa menjelaskan bahwa dari semua yang dibeli ibu yang telah diketahui, selanjutnya akan merubah pecahan desimal kedalam pecahan biasa dan menyamakan penyebutnya terlebih dahulu, setelah itu semua belanjaan ibu dijumlahkan.

Dari jawaban siswa menunjukkan bahwa siswa mampu menemukan strategi yang akan digunakan untuk menemukan jawaban, akan tetapi pada tahap menyelesaikan soal siswa tidak menuliskan strategi penyelesaian dengan mengubah pecahan desimal menjadi pecahan biasa pada lembar jawabannya. Namun, siswa mampu menyelesaikan soal dengan strategi yang dipilihnya. Hal ini dapat dilihat pada lembar jawaban siswa.

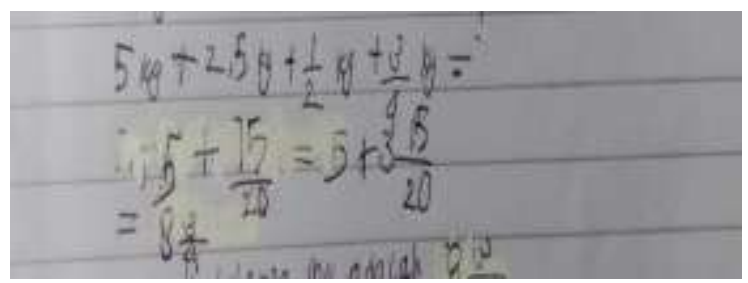

Gambar 8. Jawaban Siswa Soal Nomor 3 Tahap Menyelesaikan Soal 
Pada tahap memberi kesimpulan yang logis, siswa juga mampu menarik kesimpulan yang logis dengan jawaban yang telah diberikan, walaupun kesimpulan pada lembar jawaban siswa hanya menuliskan kesimpulan yang singkat dan kurang jelas.

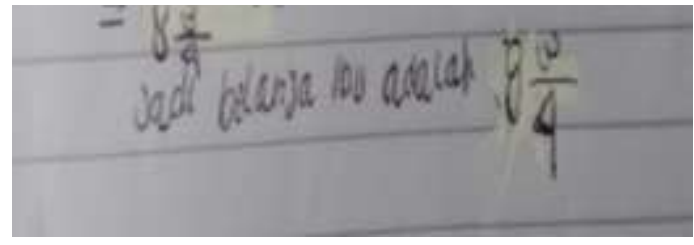

Gambar 9. Jawaban Siswa Soal Nomor 3 Tahap Memberi Kesimpulan

Pada soal nomor 4 tahap membuat makna tentang jawaban argumen yang masuk akal (memahami soal), siswa mampu menuliskan informasi yang terdapat dalam permasalahan (soal) yang diberikan. Sehingga siswa telah mampu pada tahap memahami soal yang diberikan.

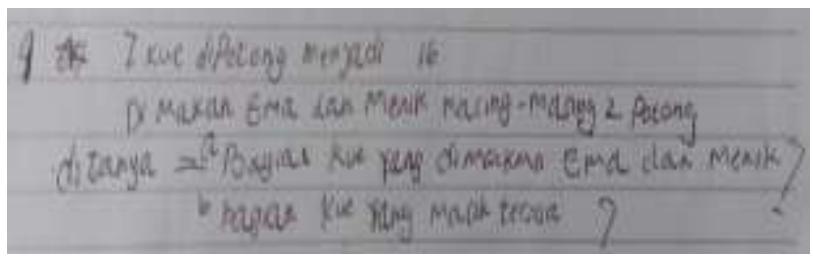

Gambar 10. Jawaban Siswa Soal Nomor 4 Tahap Memahami Soal

Pada tahap membuat hubungan logis diantara konsep dan fakta yang berbeda, menduga dan menguji berdasarkan akal (perencanaan), siswa mampu menemukan hubungan yang logis antara apa yang diketahui dan ditanyakan dalam soal. Hal ini dapat dilihat ketika ditanya, siswa pertama menjelaskan bahwa 1 kue dibagi menjadi 16 potongan kue yang sudah diketahui, selanjutnya akan dicari bagian kue yang dimakan Ema dan Menik dan juga sisa kue yang dimiliki ibu.

Siswa juga mampu menemukan strategi yang dapat digunakan untuk menemukan jawaban. Hal ini dapat dilihat pada lembar jawaban siswa. Pada tahap menyelesaikan soal, siswa menuliskan strategi penyelesaian dengan menjumlahkan semua bagian kue yang dimakan Ema dan Menik, selanjutnya mengurangi 1 kue besar ibu yang dipotong menjadi 16 bagian dengan kue yang sudah dimakan Ema dan Menik. Sehingga siswa mampu menyelesaikan soal sesuai dengan rencana dan strategi yang telah dipilihnya. 


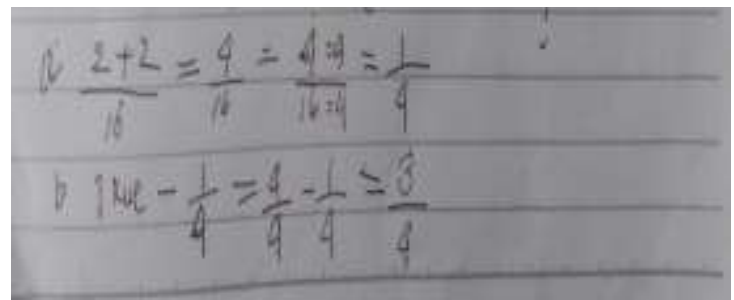

Gambar 11. Jawaban Siswa Soal Nomor 4 Tahap Menyelesaikan Soal

Namun, pada tahap menarik kesimpulan yang logis, siswa belum mampu menarik kesimpulan yang logis pada jawaban yang telah didapat. Hal ini karena siswa tidak menuliskan kesimpulan pada lembar jawabannya dan ketika ditanya pun siswa hanya menjawab tidak tahu.

\section{Pembahasan}

Berdasarkan hasil penelitian kemampuan berpikir logis matematis materi pecahan pada siswa berkemampuan awal tinggi yang telah diuraikan, maka dapat diperoleh data sebagai berikut:

Tabel 3. Aktivitas Kemampuan Berpikir Logis Matematis Materi Pecahan Pada Siswa Berkemampuan Awal Tinggi

\begin{tabular}{lcccc}
\hline \multicolumn{1}{c}{$\begin{array}{c}\text { Indikator kemampuan berfikir Logis } \\
\text { Matematis }\end{array}$} & \multicolumn{4}{c}{ Aktivitas Siswa } \\
\cline { 2 - 5 } & Soal 1 & Soal 2 & Soal 3 & $\begin{array}{c}\text { Soal } \\
\mathbf{4}\end{array}$ \\
\hline $\begin{array}{l}\text { Membuat makna tentang jawaban } \\
\text { argumen yang masuk akal }\end{array}$ & $\sqrt{ }$ & $\sqrt{ }$ & $\sqrt{ }$ & $\sqrt{ }$ \\
\hline $\begin{array}{l}\text { Membuat hubungan logis diantara konsep } \\
\text { dan fakta yang berbeda }\end{array}$ & $\sqrt{ }$ & $\sqrt{ }$ & $\sqrt{ }$ & $\sqrt{ }$ \\
\hline Menduga dan menguji berdasarkan akal & $\sqrt{ }$ & $\sqrt{ }$ & $\sqrt{ }$ & $\sqrt{ }$ \\
\hline $\begin{array}{l}\text { Menyelesaikan masalah matematis secara } \\
\text { rasional }\end{array}$ & $\sqrt{ }$ & $\sqrt{ }$ & $\sqrt{ }$ & $\sqrt{ }$ \\
\hline Menarik kesimpulan yang logis & $\sqrt{ }$ & $\sqrt{ }$ & $\sqrt{ }$ & $\mathrm{x}$ \\
\hline
\end{tabular}

Siswa dengan kemampuan awal tinggi dalam penyelesaian soal matematika materi pecahan telah mampu memenuhi kelima indikator berpikir logis matematis secara baik. Pada tahap membuat makna tentang jawaban argumen yang masuk akal siswa dengan kemampuan awal tinggi mampu memahami maksud dari soal yang diberikan dan siswa mampu menyebutkan seluruh informasi dari apa yang diketahui dari soal (merumuskan pokok-pokok permasalahan). Pada tahap membuat hubungan 
logis diantara konsep dan fakta yang berbeda, siswa berkemampuan awal tinggi telah mampu membuat hubungan logis diantara konsep dan fakta yang berbeda berupa siswa dapat merencanakan penyelesaian soal yang diberikan dan ketika proses wawancara siswa dapat mengungkapkan secara umum semua langkah yang akan digunakan dalam menyelesaikan soal yang diberikan. Pada tahap menduga dan menguji berdasarkan akal siswa mampu menentukan strategi atau langkah-langkah yang akan digunakan dalam menyelesaikan soal.

Pada tahap menyelesaikan soal, siswa berkemampuan awal tinggi mampu menyelesaikan masalah matematis secara rasional berupa siswa dapat menyelesaikan soal secara tepat pada setiap langkah yang digunakan pada lembar jawaban siswa. Kemudian pada tahap menarik kesimpulan yang logis siswa berkemampuan awal tinggi mampu memberikan kesimpulan dengan tepat pada hasil akhir jawaban. Namun, pada soal nomor 4 siswa belum mampu dalam menyimpulkan dengan tepat pada hasil akhir jawaban.

Berdasarkan pembahasan diatas dari subjek yang mewakili kemampuan berpikir logis matematis dengan kemampuan awal tinggi dapat dilihat bahwa pada penelitian ini secara umum sudah memenuhi kelima indikator berpikir logis matematis tetapi masih belum maksimal. Hal tersebut sejalan dengan hasil penelitian Akramunisa dan Andi Indra Sulestry, yang berjudul "Analisis Kemampuan Menyelesaikan Masalah Matematika Ditinjau Dari Kemampuan Awal Tinggi Dan Gaya Kognitif Field Independent (FI)" bahwa subjek Field independent (FI) dengan kemampuan tinggi dapat memikirkan langkah-langkah yang harus ditempuh walau ada kekeliruan dalam menyelesaikan masalah yang diberikan. Subjek dengan gaya kognitif field independent (FI) dipengaruhi oleh kemampuan awal, dapat terlihat subjek dengan kemampuan awal tinggi dalam menyelesaikan masalah matematika yaitu, pada kebenaran perhitungan dan kebenaran langkah-langkah penyelesaiannya dan subjek field independent (FI) lebih analitis dan terurut dan mempunyai persepsi sendiri (Akramunnisa \& Sulestry, 2016).

\section{KESIMPULAN DAN SARAN}


Berdasarkan hasil data yang didapat dalam penelitian ini, siswa dengan kemampuan awal tinggi mampu memenuhi semua indikator kemampuan berpikir logis matematis. Siswa juga mampu menunjukkan adanya aktivitas kemampuan berpikir logis matematisnya pada setiap tahap indikator berpikir logis matematis dengan baik, yaitu membuat makna tentang jawaban argumen yang masuk akal berupa siswa mampu memahami maksud dari soal yang diberikan, membuat hubungan logis diantara konsep dan fakta yang berbeda, menduga dan menguji berdasarkan akal, menyelesaikan masalah matematis secara rasional, dan menarik kesimpulan yang logis. Guru hendaknya perlu mengetahui seberapa jauh kemampuan awal berpikir logis matematis siswa untuk dimaksimalkan, agar pada pembelajaran yang akan datang bisa mendapatkan proses pembelajaran dengan hasil yang maksimal. Dan bagi siswa hendaknya terus mengasah cara berpikir logis matematisnya agar pada proses pembelajaran bisa mendapatkan hasil yang maksimal.

\section{REFERENSI}

Abdullah, I. H. (2016). Berpikir kritis matematik. Delta-Pi: Jurnal Matematika Dan Pendidikan Matematika, 2(1).

Akramunnisa, A., \& Sulestry, A. I. (2016). Analisis Kemampuan Menyelesaikan Masalah Matematika Ditinjau Dari Kemampuan awal Tinggi dan Gaya Kognitif Field Independent (FI). Pedagogy: Jurnal Pendidikan Matematika, 1(2).

Efendi, A. (2005). Revolusi kecerdasan abad 21. Bandung: Alfabeta.

Fatmahanik, U. (2019). Diagnosa Kesulitan Mahasiswa PGMI IAIN Ponorogo Dalam Membelajarkan Bilangan Pecahan. Ibriez: Jurnal Kependidikan Dasar Islam Berbasis Sains, 4(1), 133-144.

Lestari, K. E. (n.d.). M., \& Mokhammad Ridwan Yudhanegara, M.(2017). Penelitian Pendidikan Matematika. Bandung: PT Refika Aditama.

Lwin, M., Khoo, A., Lyen, K., \& Sim, C. (2008). Cara mengembangkan berbagai komponen kecerdasan. Jakarta: Indeks.

Mini, R. (2010). Panduan Mengenal dan Mengasah Kecerdasan Majemuk Anak. Jakarta: Indocam Prima. 
Purwaningrum, D., \& Sumardi. (2016a). Efek Strategi Pembelajaran Ditinjau Dari Kemampuan Awal Matematika Terhadap Hasil Belajar Matematika Kelas XI IPS. Managemen Pendidikan, 11(2), 156.

Purwaningrum, D., \& Sumardi, S. (2016b). Efek strategi pembelajaran ditinjau dari kemampuan awal matematika terhadap hasil belajar matematika kelas XI IPS. Manajemen Pendidikan, 11(2), 155-167.

Raharjo, A. T. (2010). Hubungan antara multiple intelligence dengan prestasi belajar siswa kelas XI di SMA Negeri 10 Malang. Jurnal Psikologi Tabularasa, 5(2).

Suharsimi, A. (2009). Dasar-dasar evaluasi pendidikan. Jakarta: Bumi Aksara.

Uno, H. B. (2009). Mengelola kecerdasan dalam pembelajaran. 